\title{
FAKTOR-FAKTOR YANG MEMPENGARUHI KETERLAMBATAN PERKEMBANGAN ANAK TAMAN KANAK-KANAK
}

\author{
${ }^{1}$ Moonik P \\ ${ }^{2}$ Hesti Lestari H \\ ${ }^{2}$ Rocky Wilar
${ }^{1}$ Kandidat Skripsi Fakultas Kedokteran Universitas Sam Ratulangi Manado
${ }^{2}$ Bagian Ilmu Kesehatan Anak, Fakultas Kedokteran Universitas Sam Ratulangi Manado
Email : patriciaamelia11@yahoo.com

\begin{abstract}
Development is when ability and skill increased in the structure of more complex body functions in a regular pattern and can be predicted, as a result of maturation process. This study aimed to determine the factors that influence development delay in kindergartens. Methods: This was a descriptive analytic study with cross-sectional design. The samples were 94 children who met the inclusion criterias in Kindergarten built in East Passi sub-district at Bolaang Mongondow district, October-November 2014. The development assessed using KPSP, with mark $\leq 6$ counted as delayed development progress. The data was analyzed using bivariate analysis with chi square statistic test. Results: Prenatal infections, nutritional status, breastfeed, health care, parents' income, parental education and number of siblings do not have significant relation to child development delay where the value $(\mathrm{p}=0.05)$. Child with low birth weight had 2.4 folds of the risk for development delay (IC 95\%: 0.9 to $0.7 ; \mathrm{p}=$ 0.042). Residential density had 3.8 folds of the risk for development delay (IC 95\%: 0.8 to 17.6; $p=0.038$ ). Conclusion: Low birth weight and residential density are related to the delay in child development.
\end{abstract}

Keywords: development, low birth weight, residential density.

\begin{abstract}
Abstrak: Perkembangan adalah bertambahnya kemampuan dan keterampilan dalam struktur fungsi tubuh yang lebih kompleks dalam pola yang teratur dan dapat diramalkan, sebagai hasil proses pematangan. Penelitian ini bertujuan untuk mengetahui faktor apa saja yang mempengaruhi keterlambatan perkembangan pada anak taman kanak-kanak. Penelitian ini merupakan penelitian deskriptif analitik dengan desain penelitian potong lintang. Sampel penelitian adalah 94 anak yang memenuhi kriteria inklusi di Taman Kanak-Kanak Kecamatan Passi Timur Kabupaten Bolaang Mongondow bulan oktober-november 2014. Perkembangan di nilai dengan menggunakan KPSP, dengan nilai $\leq 6$ dikatakan keterlambatan. Analisis data dilakukan dengan analisis bivariate dengan uji statistic chi square test.Hasil penelitian memperlihatkan infeksi ibu pada masa prenatal, status gizi, pemberian ASI, perawatan kesehatan, pendapatan orangtua, pendidikan orangtua dan jumlah saudara tidak memiliki hubungan bermakna terhadap keterlambatan perkembangan anak dimana nilai $(p=0,05)$. Berat lahir rendah berisiko 2,4 kali lipat untuk mengalami keterlambatan perkembangan (KI 95\%: 0,9-0,7; $\mathrm{p}=0,042$ ). Kepadatan hunian berisiko 3,8 kali lipat untuk mengalami keterlambatan perkembangan (KI 95\% :0,8-17,6; p=0,038). Simpualn: Berat lahir rendah dan kepadatan hunian berhubungan dengan keterlambatan perkembangan anak.
\end{abstract}

Kata kunci: Perkembangan, berat lahir rendah, kepadatan hunian.

Anak merupakan dambaan setiap keluarga. Selain itu, setiap keluarga juga mengharapkan anaknya kelak bertumbuh kembang optimal (sehat fisik, mental/kognitif, dan sosial), dapat dibanggakan serta berguna bagi nusa dan 
bangsa. Sebagai aset bangsa, anak harus mendapat perhatian sejak mereka masih di dalam kandungan sampai mereka menjadi manusia dewasa. ${ }^{1}$

Perkembangan adalah perubahan yang bersifat kuantitatif dan kualiatif. Perkembangan adalah bertambahnya kemampuan dan keterampilan dalam struktur fungsi tubuh yang lebih kompleks dalam pola yang teratur dan dapat diramalkan, sebagai hasil proses pematangan. Perkembangan menyangkut adanya proses diferensiasi dari sel-sel tubuh, jaringan tubuh, organ-organ, dan sistem organ yang berkembangan sedemikian rupa sehingga masing-masing dapat memenuhi fungsinya. Termasuk juga perkembangan emosi, intelektual, dan tingkah laku sebagai hasil interaksi dengan lingkungannya. Perkembangan merupakan perubahan yang bersifat progresif, terarah dan terpadu/koheren. Progresif mengandung arti bahwa terdapat hubungan yang pasti antara perubahan yang terjadi pada saat ini, sebelumnya dan berikutnya. ${ }^{1}$

Pada umumnya anak memiliki pola perkembangan normal yang merupakan hasil interaksi banyak faktor yang mempengaruhi perkembangan anak. Faktor-faktor tersebut adalah faktor genetik dan faktor lingkungan diantaranya biofisiko-psikososial, yang bisa menghambat dan mengoptimalkan perkembangan anak. Faktor lingkungan secara garis besar di bagi menjadi faktor lingkungan prenatal, faktor lingkungan perinatal dan faktor lingkungan pascanatal. ${ }^{2}$

Pengaruh lingkingan terhadap tumbuh kembang anak sangat kompleks, tidak hanya keluarga, melainkan juga masyarakat disekitar anak, lingkungan biologis, lingkungan fisik, ekonomi-politik, serta sosial budaya. ${ }^{3}$ Perkembangan anak juga mengacu pada terpenuhinya kebutuhan anak akan ASUH, ASIH, dan ASAH. ${ }^{4}$

Dari 200 juta anak di bawah usia 5 tahun di negara-negara berkembang, lebih dari sepertiganya tidak terpenuhi potensinya untuk perkembangan. ${ }^{5}$ Tidak terpenuhinya potensi perkembangan anak diperkirakan akan menyebabkan penghasilan anak tersebut di usia dewasa berkurang sebanyak 20\% sehingga akan berimplikasi pada perkembangan nasional suatu bangsa. ${ }^{6}$

Penelitian-penelitian terdahulu menunjukkan hasil skrining perkembangan yang berbeda-beda, dengan rentang nilai sebesar $13 \%-28,5 \% .{ }^{7,8}$ Tujuh puluh persen anak dengan keterlambatan tidak teridentifikasi tanpa skrining, sedangkan 70\%-80\% anak dengan keterlambatan perkembangan teridentifikasi dengan skrining perkembangan yang baik. ${ }^{9,10}$

Penelitian di Kecamatan Klojen Kotamadya Malang, terhadap anak taman kanak-kanak (TK) selama periode penelitian bulan Agustus-Desember 2010, dengan skrining perkembangan terhadap 248 anak. Hasil skrining dengan KPSP menunjukkan 236 anak (95,1\%) anak menunjukkan perkembangan yang sesuai dan 12 anak (0,05\%) menunjukkan perkembangan meragukan atau ada penyimpangan. ${ }^{11}$

Zat gizi memiliki peranan yang sangat penting bagi kelangsungan tumbuh kembang anak dan kesehatannya. Nutrisi yang terkandung dalam ASI mencakup nutrisi, faktor kekebalan dan pertumbuhan, hormon, anti alergi, dan anti inflamasi. ${ }^{12}$

Pemberian ASI eksklusif untuk bayi yang berusia dibawah 6 bulan secara global dilaporkan kurang dari 40\%. ${ }^{13}$ Secara nasional cakupan ASI untuk bayi sampai umur 6 bulan mengalami fluktuasi, yaitu 24,3\% pada tahun 2008, kemudian meningkat pada tahun 2009 menjadi 34,3\% dan menurun pada tahun 2010 menjadi $33,6 \%{ }^{14}$

Berdasarkan penelitian di Puskesmas Nanggalo terletak di Kecamatan Nanggalo, Kota Padang dengan 3 wilayah kerja, yaitu: Kelurahan Surau Gadang, Kelurahan Kurao Pagang, dan Kelurahan Gurun Laweh. ${ }^{15}$ Diperoleh 50 sampel diantaranya 33 bayi (66\%) yang mendapat ASI eksklusif dengan pertumbuhan status gizi yang normal dan 17 bayi (34\%) yang tidak mendapat ASI eksklusif dengan pertumbuhan status gizi yang kurang. ${ }^{16}$ 
Status gizi secara langsung berkaitan dengan faktor sosial ekonomi yang meliputi tingkat pengetahuan ibu dan ayah, tingkat pendapatan per kapita, tingkat pengetahuan terhadap gizi dan jumlah anggota keluarga. ${ }^{17}$

Kuesioner Pra Skrining

Perkembangan (KPSP) merupakan salah satu alat skrining yang diwajibkan oleh Depkes untuk digunakan di tingkat pelayanan kesehatan primer. Kuesioner Pra Skrining Perkembangan (KPSP) sangat mudah digunakan baik oleh petugas kesehatan bahkan bagi guru TK (Taman Kanak-kanak), guru PAUD (Pendidikan Anak Usia Dini), maupun orangtua untuk mendeteksi dini adanya kelainan perkembangan anak sejak dini sehingga dengan cepat dapat dilakukan intervensi dini.

\section{METODE PENELITIAN}

Penelitian ini merupakan penelitian deskriptif analitik dengan desain penelitian cross sectional (potong lintang). Penelitian ini bertempat di taman kanak-kanak yang berada di wilayah Kecamatan Passi Timur Kabupaten Bolaang Mongondow. Waktu penelitian dilakukan pada bulan Oktober-November 2014. Populasi penelitian adalah semua anak-anak di wilayah Kecamatan Passi Timur Kabupaten Bolaang Mongondow dan semua orang tua yang bersedia mengikuti penelitian dengan menandatangani informed consent. Sampel adalah anak yang mengalami keterlambatan perkembangan di wilayah Kecamatan Passi Timur Kabupaten Bolaang Mongondow yang termasuk kriteria inklusi. Data yang diperoleh kemudian dikumpulkan, diolah dan disusun dengan menggunakan program Microsoft Office Word dan SPSS (Statistical Program for Social Science). Analisis data dilakukan dengan analisis bivariate dengan uji statistic chi square test berdasarkan variabel gizi, pemberian ASI, perawatan kesehatan, kepadatan hunian, pekerjaan/pendapatan keluarga, pendidikan ayah/ibu, jumlah saudara dan perkembangan anak.

\section{HASIL PENELITIAN}

Penelitian ini dilaksanakan di taman kanak-kanak yang berada di wilayah Kecamatan Passi Timur Kabupaten Bolaang Mongondow. Sampel adalah anak-anak dengan usia 4-5 tahun dan orang tua yang bersedia mengikuti penelitian, dan tercatat sebanyak 94 sampel. Dari 94 sampel tersebut, diperoleh 69 anak dengan presentase 73,4 mengalami perkembangan sesuai usia dan 25 anak dengan presentase 26,6 mengalami keterlambatan perkembangan.

Tabel 1 menunjukkan dari 94 sampel yang di dapat, terdapat 51 perempuan (54,3\%) dan laki-laki 43 sampel (45,7\%).

Tabel 1. Jumlah Sampel Berdasarkan Sebaran Jenis Kelamin

\begin{tabular}{cc}
\hline Jenis Kelamin & N (\%) \\
\hline Perempuan & $51(54,3)$ \\
Laki-laki & $43(45,7)$ \\
Jumlah & $94(100)$ \\
\hline
\end{tabular}

Pada tabel 2 dapat di lihat 55 anak mengalami perkembangan normal tanpa infeksi ibu dan 14 anak dengan infeksi ibu masa prenatal, sedangkan, keterlambatan perkembangan dialami 19 anak tanpa infeksi ibu dan 6 anak dengan infeksi ibu masa prenatal. Berdasarkan hasil uji Pearson Chi-Square di atas menyatakan tidak ada hubungan yang bermakna antara infeksi ibu masa prenatal dan perkembangan anak taman kanakkanak ( $\mathrm{p}=0,349)$.

Dari Tabel 3 dapat di lihat 56 anak mengalami perkembangan normal dengan berat lahir normal dan 13 anak dengan berat lahir rendah sedangkan, keterlambatan perkembangan dialami 16 anak dengan berat lahir normal dan 9 anak dengan berat lahir rendah. Berdasarkan hasil uji Pearson Chi-Square diatas menyatakan ada hubungan yang bermakna antara berat lahir rendah dan 
perkembangan anak taman kanak-kanak $(\mathrm{p}=0,042)$ dengan $\mathrm{OR}=2,4$ (KI 95\%: 0,9$0,7)$ berarti faktor berat lahir rendah berisiko 2,4 kali lipat untuk mengalami keterlambatan perkembangan.

Tabel 2. Hubungan Infeksi Ibu Pada Masa Prenatal dan Keterlambatan Perkembangan Anak

\begin{tabular}{cccc}
\hline Infeksi ibu masa prenatal & \multicolumn{2}{c}{ Perkembangan } & Jumlah (\%) \\
& Normal & Terlambat & \\
\hline n (\%) & $\mathrm{n}(\%)$ & $74(78,7)$ \\
Tidak Ada & $55(79,7)$ & $19(76,0)$ & $20(21,3)$ \\
Ya Ada & $14(20,3)$ & $6(24,0)$ & $94(100,0)$ \\
Jumlah & $69(100,0)$ & $25(100,0)$ & \\
\hline
\end{tabular}

Tabel 3. Hubungan Berat Lahir Anak dan Keterlambatan Perkembangan Anak

\begin{tabular}{cccc}
\hline Berat lahir anak & \multicolumn{2}{c}{ Perkembangan } & Jumlah (\%) \\
& $\begin{array}{c}\text { Normal } \\
\mathrm{n}(\%)\end{array}$ & $\begin{array}{c}\text { Terlambat } \\
\mathrm{n}(\%)\end{array}$ & \\
\hline Normal & $56(81,2)$ & $16(64,0)$ & $72(76,6)$ \\
Rendah & $13(18,8)$ & $9(36,0)$ & $22(23,4)$ \\
Jumlah & $69(100,0)$ & $25(100,0)$ & $94(100,0)$ \\
\hline
\end{tabular}

Dari Tabel 4 dapat di lihat 68 anak mengalami perkembangan normal tanpa dengan status gizi normal dan 1 anak dengan status gizi tidak normal. Sedangkan, keterlambatan perkembangan dialami 24 anak dengan statu gizi normal dan 1 anak dengan status gizi yang tidak normal. Berdasarkan hasil uji Fisher's Exact Test diatas menyatakan tidak ada hubungan yang bermakna antara status gizi dan perkembangan anak taman kanak-kanak $(\mathrm{p}=0,463)$

Dari Tabel 5 dapat di lihat 16 anak mengalami perkembangan normal dengan pemberian ASI eksklusif dan 53 anak tidak diberikan ASI eksklusif. Sedangkan, keterlambatan perkembangan dialami 7 anak dengan pemberian ASI eksklusif dan 23 anak tidak diberikan ASI eksklusif. Berdasarkan hasil uji Pearson Chi-Square tidak ada hubungan yang bermakna antara pemberian ASI dan perkembangan anak taman kanak-kanak $(\mathrm{p}=0,316)$.

Dari Tabel 6 dapat di lihat 68 anak mengalami perkembangan normal dengan perawatan kesehatan yang baik dan 1 anak dengan perawatan kesehatan yang buruk sedangkan keterlambatan perkembangan dialami 23 anak dengan perawatan kesehatan yang baik dan 2 anak dengan perawatan kesehatan yang buruk. Hasil uji Fisher's Exact Test diatas menyatakan tidak ada hubungan yang bermakna antara perawatan kesehatan dan perkembangan anak taman kanak-kanak ( $\mathrm{p}=0,172$ ).

Dari Tabel 7 dapat dilihat 17 anak mengalami perkembangan normal dengan keadaan hunian yang tidak padat dan 52 anak dengan keadaan rumah yang padat. Keterlambatan perkembangan dialami 2 anak dengan keadaan hunian yang tidak padat dan 23 anak dengan keadaan hunian yang padat. Berdasarkan hasil uji Pearson Chi-Square diatas menyatakan ada hubungan yang bermakna antara kepadatan hunian dan perkembangan anak taman kanak-kanak ( $\mathrm{p}=0,038)$ dengan $\mathrm{OR}=3,8$ (KI 95\%:0,8-17,6) berarti faktor kepadatan hunian berisiko 3,8 kali lipat untuk mengalami keterlambatan perkembangan. 
Jurnal e-Clinic (eCl), Volume 3, Nomor 1, Januari-April 2015

Tabel 4. Hubungan Status Gizi dan Keterlambatan Perkembangan Anak

\begin{tabular}{cccc}
\hline Status Gizi & \multicolumn{2}{c}{ Perkembangan } & Jumlah (\%) \\
& Normal & Terlambat & \\
& $\mathrm{n}(\%)$ & $\mathrm{n}(\%)$ & $92(97,9)$ \\
\hline Normal & $68(98,6)$ & $24(96,0)$ & $2(2,1)$ \\
Tidak Normal & $1(1,4)$ & $1(4,0)$ & $94(100,0)$ \\
Jumlah & $69(100,0)$ & $25(100,0)$ & \\
\hline
\end{tabular}

Tabel 5. Hubungan Pemberian ASI dan Keterlambatan Perkembangan Anak

\begin{tabular}{cccr}
\hline Pemberian ASI & \multicolumn{2}{c}{ Perkembangan } & Jumlah (\%) \\
& Normal & Terlambat & \\
& $\mathrm{n}(\%)$ & $\mathrm{n}(\%)$ & $23(24,5)$ \\
\hline Eksklusif & $16(23,2)$ & $7(28,0)$ & $71(75,5)$ \\
Tidak Eksklusif & $53(76,8)$ & $23(72,0)$ & $94(100,0)$ \\
Jumlah & $69(100,0)$ & $25(100,0)$ & \\
\hline
\end{tabular}

Tabel 6. Hubungan Perawatan Kesehatan dan Keterlambatan Perkembangan Anak

\begin{tabular}{crrr}
\hline Perawatan Kesehatan & \multicolumn{2}{c}{ Perkembangan } & Jumlah (\%) \\
& Normal & Terlambat & \\
\hline n (\%) & n (\%) & $3(3,2)$ \\
Baik & $68(98,6)$ & $23(92,0)$ & $91(96,8)$ \\
Jumlah & $1(1,4)$ & $2(8,0)$ & $94(100,0)$ \\
\hline
\end{tabular}

Tabel 7. Hubungan Kepadatan Hunian dan Keterlambatan Perkembangan Anak

\begin{tabular}{cccc}
\hline Kepadatan Hunian & \multicolumn{2}{c}{ Perkembangan } & Jumlah (\%) \\
& Normal & Terlambat & \\
& $\mathrm{n}(\%)$ & $\mathrm{n}(\%)$ & $19(20,2)$ \\
\hline Tidak Padat & $17(24,6)$ & $2(8,0)$ & $75(79,8)$ \\
Padat & $52(75,4)$ & $23(92,0)$ & $94(100,0)$ \\
Jumlah & $69(100,0)$ & $25(100,0)$ & \\
\hline
\end{tabular}

Dari Tabel 8 dapat di lihat 48 anak mengalami perkembangan normal dengan pendapatan keluarga yang tinggi dan 21 anak dengan pendapatan rendah. Sedangkan, keterlambatan perkembangan dialami 13 anak dengan pendapatan keluarga yang tinggi dan 12 anak dengan pendapatan yang rendah. Berdasarkan hasil uji Pearson Chi-Square diatas menyatakan tidak ada hubungan yang bermakna antara pendapatan keluarga dan perkembangan anak taman kanak-kanak ( $\mathrm{p}=0,057)$.

Dari Tabel 9 dapat di lihat 50 anak mengalami perkembangan normal dengan tingkat pendidikan orangtua yang tinggi dan 19 anak dengan tingkat pendidikan yang rendah. Sedangkan, keterlambatan perkembangan dialami 15 anak dengan tingkat pendidikan orantua yang tinggi dan 10 anak dengan tinggkat pendidikan orangtua yang rendah. Berdasarkan hasil uji Pearson Chi-Square diatas menyatakan tidak ada hubungan yang bermakna antara pendidikan orangtua dan perkembangan anak taman kanak-kanak ( $\mathrm{p}=0,124$ ).

Dari Tabel 10 dapat di lihat 47 anak mengalami perkembangan normal dengan 
jumlah saudara yang sedikit dan 22 anak dengan jumlah saudara yang banyak. Sedangkan, keterlambatan perkembangan dialami 7 anak dengan jumlah saudara yang sedikit dan 18 dengan jumlah saudara yang banyak. Berdasarkan hasil uji Pearson Chi-Square diatas menyatakan tidak ada hubungan yang bermakna antara jumlah saudara dan perkembangan anak taman kanak-kanak ( $\mathrm{p}=0,359$ ).

Tabel 8. Hubungan Pendapatan Keluarga dan Keterlambatan Perkembangan Anak

\begin{tabular}{cccc}
\hline Pendapatan Keluarga & \multicolumn{2}{c}{ Perkembangan } & Jumlah (\%) \\
& $\mathrm{n}$ (\%) & $\begin{array}{c}\text { Terlambat } \\
\mathrm{n}(\%)\end{array}$ & \\
\hline Tinggi & $48(69,6)$ & $13(52,2)$ & $61(64,9)$ \\
Rendah & $21(30,4)$ & $12(48,0)$ & $33(35,1)$ \\
Jumlah & $69(100,0)$ & $25(100,0)$ & $94(100,0)$ \\
\hline
\end{tabular}

Tabel 9. Hubungan Pendidikan Orangtua dan Keterlambatan Perkembangan Anak

\begin{tabular}{cccc}
\hline Pendidikan Orang Tua & \multicolumn{2}{c}{ Perkembangan } & Jumlah (\%) \\
& $\begin{array}{c}\text { Normal } \\
\mathrm{n}(\%)\end{array}$ & $\begin{array}{c}\text { Terlambat } \\
\mathrm{n}(\%)\end{array}$ & \\
\hline Tinggi & $50(72,5)$ & $15(60,0)$ & $65(69,1)$ \\
Rendah & $19(27,5)$ & $10(40,0)$ & $29(30,9)$ \\
Jumlah & $69(100,0)$ & $25(100,0)$ & $94(100,0)$ \\
\hline
\end{tabular}

Tabel 10. Hubungan Jumlah Saudara dan Keterlambatan Perkembangan Anak

\begin{tabular}{cccc}
\hline Jumlah Saudara & \multicolumn{2}{c}{ Perkembangan } & Jumlah (\%) \\
& $\mathrm{n}(\%)$ & $\begin{array}{c}\text { Terlambat } \\
\mathrm{n}(\%)\end{array}$ & \\
\hline Sedikit & $47(68,1)$ & $7(28,0)$ & $29(30,9)$ \\
Banyak & $22(31,9)$ & $18(72,0)$ & $65(69,1)$ \\
Jumlah & $69(100,0)$ & $25(100,0)$ & $94(100,0)$ \\
\hline
\end{tabular}

\section{BAHASAN}

Penelitian ini dilaksanakan di taman kanak-kanak yang berada di wilayah Kecamatan Passi Timur Kabupaten Bolaang Mongondow. Sampel adalah anakanak dengan usia 4-5 tahun dan orangtua yang bersedia mengikuti penelitian, dan tercatat sebanyak 94 sampel. Dari 94 sampel, 51 diantaranya adalah perempuan 54,3\% dan laki-laki 45,7\%. Dari 94 sampel tersebut, diperoleh 69 anak dengan presentase 73,4 mengalami perkembangan sesuai usia dan 25 anak (26,6\%) mengalami keterlambatan perkembangan.

Berdasarkan uji Pearson Chi-Square hasil penelitian didapatkan bahwa infeksi ibu pada masa prenatal tidak memiliki hubungan bermakna terhadap keterlambatan perkembangan anak dimana $\mathrm{p}=$ 0,349 . Hasil penelitian yang peroleh tidak bermakna karena nilai $\mathrm{p}>0,05$. Hasil penelitian ini dibandingkan dengan teori yang menyatakan bahwa; Infeksi intrauterine yang sering menyebabkan 
cacat bawaan ialah TORCH (toxoplasmosis, rubella, cytomegalovirus, herpes simplex). Sedangkan, infeksi lainnya yang juga dapat menyebabkan penyakit pada janin adalah varisella, coxsakie, echovirus, malaria, sifilis, HIV, polio, campak, listeriosis, leptospira, mikoplasma, virus influenza, dan virus hepatitis.

Tidak didapatkanya hubungan bermakna karena dalam penelitian ini peneliti tidak melakukan pemeriksaan serologi untuk menunjang diagnosis TORCH. Peneliti hanya melakukan anamnesis mengenai beberapa gejala seperti demam, merah dikulit dan keputihan yang banyak. Jadi, mungkin infeksi yang dialami ibu bukan disebabkan karena TORCH.

Berdasarkan uji Pearson Chi-Square hasil penelitian didapatkan bahwa berat lahir anak memiliki hubungan bermakna terhadap keterlambatan perkembangan anak dimana $\mathrm{p}=0,042$, dengan $\mathrm{OR}=2,4$. Hasil penelitian sebelumnya menyatakan bahwa 55,6\% anak usia prasekolah memiliki status gizi waktu lahir baik dan sebanyak 44,4\% anak usia prasekolah memiliki status gizi dengan BBLR.

Pada saat ini mereka sedang mengalami proses pertumbuhan relatif pesat, dan memerlukan zat-zat gizi dalam jumlah relatif besar. Pertumbuhan yang relatif pesat misalnya pertumbuhan fisik dan perkembangan kecerdasan. ${ }^{18}$ Menurut Gutama (2004) anak yang lahir dengan BBLR akan mengalami gangguan fungsi kognitif dan kecerdasan intelegtual pada usia pra sekolah.

Berdasarkan uji Fisher's Exact Test hasil penelitian didapatkan bahwa status gizi anak tidak memiliki hubungan bermakna terhadap keterlambatan perkembangan anak dimana $\mathrm{p}=0,463$. Hasil penelitian ini dibandingkan dengan penelitian sebelumnya menyatakan bahwa prevalensi gangguan pertumbuhan pada anak usia sekolah di Indonesia sebesar 32\% di pedesaan dan $18 \%$ di wilayah perkotaan. Anak yang kurang gizi akan berpotensi mengalami gangguan pertumbuhan fisik dan perkembangan mentalnya. ${ }^{19}$

Berdasarkan uji Pearson Chi-Square hasil penelitian didapatkan bahwa pemberian ASI tidak memiliki hubungan bermakna terhadap keterlambatan perkembangan anak dimana $\mathrm{p}=0,316$. Hasil penelitian ini tidak sebanding dengan penelitian yang dilakukan oleh Ni Made di Puskesmas Karanganyar tahun 2010 bahwa terdapat hubungan yang signifikan antara pemberian ASI dengan perkembangan bayi. $^{20}$

Penelitian Novita dkk (2007) di lingkungan Cigondewah, Bandung menyimpulkan bahwa aspek kognitif pada bayi yang mendapat ASI eksklusif memberi hasil yang baik dibandingkan dengan bayi yang tidak mendapat ASI eksklusif. $^{21}$ Hubungan pemberian ASI tidak bermakna dengan keterlambatan perkembangan mungkin disebabkan oleh kualitas dan kuantitas pemberian ASI yang tercapai dengan baik.

Berdasarkan uji Fisher's Exact Test hasil penelitian didapatkan bahwa perawatan kesehatan anak tidak memiliki hubungan bermakna terhadap keterlambatan perkembangan anak dimana $\mathrm{p}=0,172$. Hubungan perawatan kesehatan tidak bermakna dengan keterlambatan perkembangan mungkin disebabkan oleh semakin tingginya tingkat kesadaran perawatan kesehatan oleh orangtua ketika anak sakit, imunisasi yang rutin, termasuk pemantauan pertumbuhan, dengan menimbang anak secara rutin setiap bulan. ${ }^{1}$

Berdasarkan uji Pearson Chi-Square hasil penelitian didapatkan bahwa kepadatan hunian memiliki hubungan bermakna terhadap keterlambatan perkembangan anak dimana $\mathrm{p}=0,038$, dengan $\mathrm{OR}=3,8$. Jadi, tingkat kepadatan hunian mempunyai hubungan yang bermakna secara statistik dengan kejadian keterlambatan perkembangan. Hasil penelitian ini sama seperti teori yang menyatakan bahwa keadaan perumahan yang layak, dengan konstruksi bangunan yang tidak membahayakan penghuninya, serta tidak penuh sesak, akan menjamin kesehatan penghuninya. ${ }^{1}$ Kesehatan 
penghuninya berarti mencakup aspek perkembangan anak.

Berdasarkan uji Pearson Chi-Square hasil penelitian didapatkan bahwa pendapatan keluarga tidak memiliki hubungan bermakna terhadap keterlambatan perkembangan anak dimana $\mathrm{p}=0,057$. Itu mungkin disebabkan karena pendapatan masyarakat diatas rata-rata yang berimplikasi kepada pemenuhan segala bentuk kebutuhan yang berdampak kepada pertumbuhan anak yang baik.

Berdasarkan uji Pearson Chi-Square hasil penelitian didapatkan bahwa pendidikan orangtua tidak memiliki hubungan bermakna terhadap keterlambatan perkembangan anak dimana $\mathrm{p}=0,124$. Hubungan pendidikan orangtua tidak bermakna dengan keterlambatan perkembangan mungkin

\section{SIMPULAN}

Dari hasil penelitian ini dapat disimpulkan bahwa berat lahir rendah dan kepadatan hunian berhubungan dengan keterlambatan perkembangan anak.

\section{SARAN}

1. Perlu adanya pencegahan terhadap risiko kelahiran bayi dengan berat lahir rendah.

2. Perlu adanya perhatian orangtua mengenai kepadatan hunian.

3. Perlu penelitian lebih lanjut tentang faktor-faktor yang mempengaruhi keterlambatan perkembangan pada anak.

Hasil penelitian ini telah disampaikan kepada orangtua anak, baik yang mengalami keterlambatan perkembangan maupun yang perkembangannya normal. Peneliti memberikan penyuluhan agar orangtua dapat memperhatikan setiap aspek yang membantu proses perkembangan anak, dimana orangtua bisa memberikan stimulasi kepada anak dan anak mendapat pemeriksaan kesehatan yang teratur. Bagi orangtua yang anaknya mengalami keterlambatan perkembangan, peneliti menganjurkan untuk melakukan pemeriksaan perkembangan kembali pada petugas kesehatan dua minggu setelah pemeriksaan tersebut.

\section{DAFTAR PUSTAKA}

1. Soetjiningsih. Konsep Dasar Tumbuh Kembang Anak. In: Ranuh IGNG, penyunting. Tumbuh Kembang Anak. Edisi 2. Jakarta: EGC, 2012.h.2-3.

2. Soetjiningsih. Faktor-Faktor Yang Mempengaruhi Tumbuh Kembang Anak. In: Ranuh IGNG, penyunting. Tumbuh Kembang Anak. Edisi 2. Jakarta: EGC, 2012.h.61-71.

3. Ebrahim GJ. Social and Comumunity Paediatrics in Developing Countries, Caring for The Ryral and Urban Poor. $1^{\text {st }}$ Ed. Macmillan, London, 1985.

4. Titi S. Sularyo. Pertumbuhan Linier (Stature) anak dan upaya pemantauannya dengan minat pada perawakan pendek, Naskah Lengkap: Masalah penyimpangan.

5. UNICEF. Programming Experiences in Early Child Development. New York : Early Child Development Unit Press; 2006.

6. Grantham-McGregor, Cheung, Cueto, Glewwe, Richter, Strupp, et al. Developmental Potential in The First 5 Years for Children in Developing Countries. Lancet. 2007; 369: 60-70.

7. Fadlyana E, Alisjahbana A, Nelwan I, Noor M, Selly, Sofiyatin Y. Pola Keterlambatan Perkembangan Balita di daerah Pedesaan dan Perkotaan serta Faktor-faktor yang Mempengaruhnya. Sari Pediatri. 2003; 4(4): 168-75.

8. Tim Peneliti Direkorat Bina Kesehatan Keluarga dan Direktorat Kesehatan Jiwa. Laporan Akhir Penelitian Pengembangan Paket Pemantauan Perkembangan Anak. Jakarta: Departemen Kesehatan Republik Indonesia; 1990.

9. Centers for Health Care Strategies. Improving Developmental Screening: One Child at Time. (Online) September $2004 . \quad$ http://www.chcs.org/ publications3960/publications_show.ht m?doc_id=6 23283 [diakses tanggal 10 Mei 2012].

10.Schol EL. Best Practices in Developmental Screening and Services. (Online) 10 Mei 2012. http:// 
www.earlychildhoodnm.com/Documen ts/5-05 [diakses tanggal 10 Mei 2012].

11.Ariani, Mardhani Yasoprawoto.2012. Usia Anak dan Pendidikan Ibu Sebagai Faktor Resiko Gangguan Perkembangan Anak. Jurnal Kedokteran Brawijaya. Vol.27:118-21.

12.Suradi R. Manfaat ASI dan kerugian susu formul. Jakarta: Balai Penerbit FKUI; 2008.

13.WHO. Infant feeding recommendation [serial online] 2008. (diunduh 5 Januari 2013). Tersedia dari: URL: HYPERLINK

http://www.who.int/nutrition/topics/inf antfeeding_recommendation/en/index.h tml

14. Kemenkes RI. Kinerja kegiatan pembinaan gizi tahun 2011. Jakarta: 2011.

15.Laporan Puskesmas Nanggalo. Padang: 2011.

16.Dian Insana F, Eva C, Rima S. Hubungan pemberian ASI dengan tumbuh kembang bayi umur 6 bulan di Puskesmas Nanggalo. Jurnal Kesehatan Andalas. 2014; 3(2): 137-9.

17.Aeda E. Hubungan faktor sosial ekonomi, higiene, sanitasi lingkungan, tingkat konsumsi dan infeksi dengan status gizi anak usia 2-5 tahun di kabupaten semarang tahun 2003. Universitas Diponegoro. Semarang: 2006.
18.Sutriani NK, Wulandari Dewi AR. Hubungan status gizi waktu lahir dengan perumbuhan dan perkembangan anak usia prasekolah di desa Peguyangan, kota Denpasar. Jurnal Ilmu Gizi. 2011;2(2):109-17.

19.Setionegoro D. 2007. Pengaruh gizi terhadap tumbuh kembang anak. Bogor: IPB.

20.Lidya, Ni Made, Rodiah. Hubungan pemberian ASI dan tumbuh kembang pada anak usia 3 sampai 6 bulan di Puskesmas Karanganyar. [serial online] 2010. (diunduh 12 juni 2013). Tersedia dari: URL: HYPERLINK http://www.ejurnal.dinkesjatenprov.go. id

21.Novita L, Dida Z, Gumida, Herry G. Perbandingan fungsi kognitif bayi usia 6 bulan yang mendapat ASI eksklusif dan yang tidak mendapat ASI eksklusif. Sari Pediatri. 2007;9(6);42934.

22.Lllingworth RS. The Normal Child. Edisi ke-10. Edinburgh: Churchill Livingstone; 1991;p.167-88.

23.Isaranurug $S$, Nathamongkolchai $S$, Kaewsiri D. Factor Influencing Development Of Children Aged One to Under Six Years Old. Jurnal of the Medical Association Thailand. 2005;88(1):86-90. 